\title{
Autoimmunity in Hepatitis C Virus Infection - An Immunologist's Perspective
}

\author{
Meilyn Hew ${ }^{1}$, Christine Bundell1,2, Pooja Deshpande ${ }^{3}$, Silvana Gaudieri ${ }^{3,4,5}$ and Michaela Luca \\ ${ }^{1}$ Department of Clinical Immunology, Queen Elizabeth II Medical Centre, Australia \\ ${ }^{2}$ School of Pathology and Laboratory Medicine, University of Western Australia, Australia \\ ${ }^{3}$ School of Anatomy, Physiology and Human Biology, University of Western Australia, Australia \\ ${ }^{4}$ Institute for Immunology and Infectious Diseases, Murdoch University, Australia \\ ${ }^{5}$ Department of Medicine, Vanderbilt University, USA \\ ${ }^{6}$ School of Medicine and Pharmacology, University of Western Australia, Australia
}

Submission: February 27, 2017; Published: April 05, 2017

*Corresponding authors: Michaela Lucas, Department of Clinical Immunology, Queen Elizabeth II Medical Centre, Australia, Tel: +61 864573333 ;

Fax: +61 86457 3160; Email: Michaela.Lucas@health.wa.gov.au

Abstract

Hepatitis C virus infection can be associated with the presence of auto antibodies and clinical disease which may have significant morbidity in this population. Manifestations can be systemic or organ specific. This review presents the current state of play on autoimmunity in Hepatitis C in the absence of interferon-alpha based treatment, from a clinical immunologist's perspective.

Keywords: Hepatitis C virus; Autoimmunity; Thyroid disease; Arthropathy; Cryoglobulins; Sicca symptoms; Sjogren's Immunity; Interferon

Abbreviations: AAb: Auto Antibodies; AECG: American-European Consensus Group; AIH: Autoimmune Hepatitis; AMA: Anti-Mitochondrial Antibody; ANA: Anti-Nuclear Antibody; ASMA: Anti-Smooth Muscle Antibody; CCP: Cyclic Citrullinated Peptide; DAA: Direct Acting Antivirals; GT: Genotype; HCV: Hepatitis C Virus; HBV: Hepatitis B Virus; IF: Intrinsic Factor; IFN: Interferon; LDL: Low Density Lipoprotein; LKMA1: Liver Kidney Microsomal Antibody 1; MC: Mixed Cryoglobulinaemia; MCV: Mutated Citrullinatedvimentin Antibody; NOSA: Non-Organ Specific Autoantibody; pSS: primary Sjogren's Syndrome; RA: Rheumatoid Arthritis; RF: Rheumatoid Factor; SP: Symmetric Polyarthropathy; SS: Sjogren's Syndrome; sSS: Secondary Sjogren's Syndrome; T3: Tri-Iodothyronine; T4: Thyroxine; TFT: Thyroid Function Test; Tg: Thyroglobulin; TPO: Thyroid Peroxidase; TSH: Thyroid Stimulating Hormone

\section{Introduction}

Hepatitis C Virus (HCV) infection is commonly thought of being associated with an increased incidence of autoimmunity. However, the immunological basis behind this heightened susceptibility to autoimmunity is not well understood. It is not clear whether HCV infection itself induces autoimmunity, how this differs compared to other viral hepatitis infections, or if the presence of autoimmunity is confounded by the previously widespread use of interferon-alpha based regimens for the treatment of HCV. Therefore, in the current era of interferonfree treatments based on direct acting anti-viral (DAA), do clinicians need to remain vigilant for autoimmune complications in their patients? This review summarises current evidence to assist clinicians with the management of subjects with HCV and when to suspect autoimmunity. As the majority of evidence in regards to $\mathrm{HCV}$ and autoimmunity is related to B cell mediated autoimmunity, with the association of auto antibodies (AAb), this will be the focus of this review. Overall, while published evidence generally distinguishes between HCV with and without interferon treatment, there are only a few studies that include relevant healthy age and gender matched control populations.

\section{HCV interferes with normal B cell regulation}

Although HCV is primarily hepatotrophic, there is evidence to suggest that the virus is able to directly infect lymphoid cells [1], including B cells [2] via interaction of HCV envelope protein E2 and the cell surface protein CD81. Following this, there is increased expression of the anti-apoptotic B cell survival factor Bcl-2 in B cells and protection of B cells from Fasmediated apoptosis [3-6], implying prolonged B cell survival and protection from activation-induced death. 
CD81 forms part of the B cell co stimulatory complex that includes CD19, CD21 and the IFN-inducible protein CD225 that can reduce the threshold for $\mathrm{B}$ cell activation following antigenstimulation. Following HCV E2-CD81 binding, there are reports of up-regulation of co stimulatory markers CD80 and CD86 [6] on B cells leading to their non-specific polyclonal activation [7] resulting in hyper gamma globulinaemia. This is further supported by the high incidence $(10-70 \%)$ of cryoglobulinaemia in subjects with chronic HCV infection [8].

The viral protein NS5A also increases the activity of the protein Fyn, which is a member of the Src family of kinases, leading to an increase in cell cycling and consequent $B$ cell proliferation [9].

All of the above mechanisms are thought to contribute to B cell dysregulation, with the presumed potential for the induction of AAbs. Furthermore, there is also evidence to suggest that liver cirrhosis itself, leads to B cell abnormalities in the CD27+IgM+ memory B cell compartment [10].

Table 1: Auto antibodies described in Hepatitis C infection.

\begin{tabular}{|c|c|c|}
\hline System & $\mathbf{A A b}$ & Associated Autoimmune Disease \\
\hline $\begin{array}{l}\text { Organ specific } \\
\text { Thyroid } \\
\text { Gastrointestinal } \\
\text { Joints } \\
\text { Haematological }\end{array}$ & $\begin{array}{c}\text { TPO (thyroid peroxidase) } \\
\text { Tg (thyroglobulin) } \\
\text { IF (intrinsic factor) } \\
\text { AMA (anti-mitochondrial) } \\
\text { ASMA (anti-smooth muscle) } \\
\text { LKMA-1 (liver kidney microsomal antibody 1) } \\
\text { CCP (cyclic citrullinated peptide) } \\
\text { MCV (mutated citrullinatedvimentin) } \\
\text { Anti-platelet } \\
\text { N/A }\end{array}$ & $\begin{array}{c}\text { Thyroiditis (hyper/hypothyroidism) } \\
\text { Pernicious anaemia } \\
\text { Primary biliary cirrhosis } \\
\text { Autoimmune hepatitis type } 1 \\
\text { Autoimmune hepatitis type } 2 \\
\text { Rheumatoid arthritis } \\
\text { Rheumatoid arthritis } \\
\text { Immune thrombocytopaenia } \\
\text { Autoimmune haemolytic anaemia }\end{array}$ \\
\hline Non-organ specific & $\begin{array}{c}\text { ANA (anti-nuclear antibodies) } \\
\text { SS-A/Ro, SS-B/La } \\
\text { RF (rheumatoid factor) }\end{array}$ & $\begin{array}{c}\text { SLE, Systemic sclerosis, Sjogren'ssyndrome, } \\
\text { autoimmune hepatitis } \\
\text { Sjogren's syndrome, congenital heart block, } \\
\text { neonatal lupus } \\
\text { Associated with rheumatoid arthritis, infection/ } \\
\text { inflammation }\end{array}$ \\
\hline
\end{tabular}

Several AAbs have been described at increased frequency in HCV infection; for most of these the level of evidence is Level 3 or 4. Table 1 summarises the antibodies studied and their clinical disease associations.

\section{Hepatitis $\mathrm{C}$ and thyroid disease}

It is well established that thyroid autoimmunity, whether subacute or clinically manifest, may emerge during the course of HCV infection, even in the absence of IFN- $\alpha$ treatment. Between $2 \%$ and $48 \%$ of patients with chronic HCV infection manifest antithyroid antibodies, with the variability in prevalence attributed to a number of factors including geography, study population ethnicity [23,24], iodine intake [25] and HCV genotype (GTs) [26-28].

\section{AAbs in HCV-general considerations}

AAbs are defined as antibodies directed against self. They can be directly pathogenic in the associated autoimmune disease, or "marker" antibodies that are not directly pathogenic [11].

Low levels of AAbs are commonly present in healthy subjects, often more so in females and also increase with age [12-16]. It is thought that the positive predictive value for clinical disease increases with higher titre and may precede clinical disease by more than five years [17-19]. Overall, the presence of AAbs in serum is not synonymous with presence of autoimmune disease, which is relevant in the context of HCV studies, as many looked at the presence of AAbs, but not clinical disease.

Furthermore, the sensitivity and specificity of the autoantibody result depends on the assay and antigenic target that was used to measure the autoantibody; newer assays are generally more sensitive and use more specific targets [20-22]. Therefore, older studies using historical assays may not be easily reproduced with the newer assays. 
the controls, and $17 \%$ had anti-thyroglobulin antibodies versus 9-10\% of controls. These findings were confirmed by further studies [30] and three meta-analyses verified a significant association between HCV infection and thyroid autoimmunity $[31,32]$. Overall, female gender and anti-TPO antibody positivity was associated with a raised risk of hypothyroidism [25,33] in these studies. Nevertheless, an increased risk of thyroiditis associated with HCV infection was also demonstrated in a cohort study of predominantly male subjects (97\%) attending US Veterans Affairs Health Care facilities from 1997-2004 [34].

Thyroid autoimmunity has been studied in the presence of mixed cryoglobulinaemia (MC). Although few in number, these studies suggest that MC-positive HCV-infected subjects have a higher incidence of autoimmune thyroid disease as compared to MC-negative HCV-infected subjects; this is most pronounced in females with TPOAAbs, leading to the recommendation that female subjects with MC-positive HCV infection should be screened for thyroid autoimmunity [30].

Importantly, several studies suggest that chronic HCV infection and thyroid autoimmunity may be associated with a higher rate of papillary thyroid cancer. Antonelli, et al. [35] described a higher prevalence of this papillary thyroid cancer in 139 HCV-infected subjects compared to controls [35] while another case control study for various cancers noted an association between HCV and thyroid cancer (OR 2.8 p=0.01) $[35,36]$. The increased risk for thyroid cancer is also true for HCV-infected subjects with MC [37]. Significant lymphocytic infiltrates in the thyroid tissue were seen in the cases of HCV-associated thyroid cancer; supporting the notion that autoimmune thyroiditis may be a predisposing factor $[38,39]$. Case studies have also reported that more aggressive thyroid cancers can be seen within HCV-infected subjects [40], leading to clinical recommendations to monitor HCV-infected subjects with thyroid disease for the development of thyroid cancer.

\section{Hepatitis $\mathrm{C}$ and autoimmune arthritis}

Arthralgia is a common symptom in subjects with HCV infection [41] and asymptomatic inflammatory joint changes have been described in the majority of subjects in an HCVinfected cohort when screened by joint ultrasonography [42]. Clinically manifest arthritis in HCV-infected subjects is seen in approximately 4\% [43]. HCV-associated arthritis usually manifests as a symmetric polyarthritis (SP) or an intermittent oligoarthritis (IMO) of medium to large joints; the latter often in patients with MC.

Compared to thyroid autoimmunity, autoantibody profiling for HCV-associated arthropathy is less studied. Anti-cyclic citrullinated peptide (CCP) antibodies, which are highly specific for rheumatoid arthritis (RA) and are found in $60 \%$ to $75 \%$ of patients with RA [44,45], but can be also seen in a small proportion of patients with HCV-related arthritis $(4.5 \%$ to 7\%) [46-48].The majority of HCV-related arthritis is, however, thought to be CCP negative. This is supported by a recent study [49] investigating the prevalence of anti-mutated citrullinated vimentin (MCV) antibodies, CCP antibodies, rheumatoid factor (RF) and mixed cryoglobulinaemia (MC) in 45 subjects with HCV (GT4) infection-associated arthritis compared to 30 RA subjects. The most frequent clinical presentation was a symmetric polyarthropathy (SP), which in RA subjects was associated with CCP antibodies but not in HCV-infected subjects. Other antibodies studied such as MCV (30\% in HCV-infected subjects versus 93.3\% in RA subjects) did not aid further clinical distinction between RA and HCV-associated arthritis. In this particular study the level of RF positivity was high in both cohorts $73.3 \%$ in HCV arthropathy versus $86.7 \%$ in RA subjects. A potential role for CCP antibodies in distinguishing HCV-associated SP from RA was identified in further studies $(0 \%$ to $11.7 \%$ CCP positivity in HCV-associated disease depending on demographics of the population studied) [48,50-52]. Finally, a large nation-wide study from Taiwan revealed that in the Taiwanese population chronic HCV infection alone was associated with an increased risk for SP (hazard ratio 2.03). Due to the nature of the study no distinction between $\mathrm{HCV}$-associated SP and RA was made and no data on anti-CCP antibody profiles were provided [53].

\section{Hepatitis C and S jogren's syndrome}

$\mathrm{S}$ jogren's syndrome (SS) is a chronic, auto immune exocrinopathy characterised by reduced salivary and lacrimal gland function causing dry eyes and mouth ("sicca symptoms"), and extra-glandular manifestations affecting multiple organ systems [54]. It may present by itself, primary SS (pSS), or in association with another autoimmune disease such as SLE or RA, termed secondary SS. Hepatitis C virus is sialotrophic with HCV RNA found in both saliva and salivary epithelial cells it has been questioned whether HCV is directly responsible for the manifestations of sicca symptoms seen as a common extrahepatic manifestation of HCV infection [55-58] or whether the sicca symptoms and sialadenitis associated with HCV identify a subset of patients with pSS (potentially with HCV as a trigger for immune dysregulation). Epidemiological data on the association of HCV with SS depends on the criteria used which have changed over time and also depends on the background prevalence of $\mathrm{HCV}$, and the geographical location. The prevalence of HCV in patients with SS varies from $0-19 \%$. Patients are now considered to have a secondary form of SS if there is concurrent HCV infection [59].

Sjogren's syndrome is associated with the presence of AAbs to SS-A/Ro and SS-B/La antigens and has inflammatory cell infiltrates within the salivary glands that appear to vary with disease course or severity of disease [60]. Positivity for SS-A/Ro and SS-B/La antibodies in patients with HCV infection and sicca symptoms has been reported in up to $25 \%$ of HCV patients [61].

However, while some subjects with HCV have very similar features compared with non-HCV pSS [61], sialadenitis in the context of HCV generally shows sufficient aetiological, 
histopathological and genetic differences to allow differentiation between the two states $[62,63]$.

From a practical perspective, a predominantly B cell infiltrate in the salivary glands is strongly associated with hyper gamma globulinaemia, autoantibody production and clinical manifestations of salivary gland swelling. Both hypo complementaemia and glandular swelling are risk factors in SS for lympho proliferative disease [64-66]. Patients who otherwise satisfy American-European Consensus Group (AECG) criteria for pSS, but who are HCV positive, also have a high frequency of parotid enlargement and vasculitis are RF positive with $\mathrm{MC}$, have higher extra-nodal involvement in organs where HCV replicates, and a predominance of mucosa-associated lymphoid tissue lymphomas [67]. The presence of sicca symptoms in patients with HCV therefore remains a red flag to monitor for lympho proliferative disease.

\section{Hepatitis C and cryoglobulinaemia}

Hepatitis C is frequently associated with cryoglobulinaemia. Cryoglobulins are cold insoluble immune complexes that precipitate at temperatures below $37 \mathrm{oC}$ and resolublise on warming $[8,68]$. They are classified according to the type of immunoglobulin in the cryoprecipitate [68,69]: Type I cryoglobulins are typically monoclonal and associated with B cell lymphoproliferative disease; MC are Type II or III. Type II cryoglobulins are a mixture of polyclonal immunoglobulin IgG and a commonly monoclonal IgM immunoglobulin with reactivity for RF; Type III are polyclonal immunoglobulins (IgG, IgM, IgA) or polyclonal IgG with RF reactivity. Type II and III are those associated with $(50-60 \%)$ chronic viral infections, including HCV. The reported frequency of cryoglobulins in chronic HCV-infected subjects ranges from 12 to 56\%, with the highest prevalence reported in Mediterranean climates [69]. Although not a classical AAbs mediated immune disease, cryoglobulinaemia can present with a wide range of clinical features mimicking autoimmunity.

Symptoms associated with MC are variable ranging from Raynaud's phenomenon, small to medium-sized vessel vasculitis, purpura, arthalgia and asthenia to severe neurologic and renal involvement.

\section{Other extra-hepatic manifestations of Hepatitis C associated with the presence of AAbs}

Aside from the more common extra-hepatic manifestations, auto immunecytopenias have been described in association with AAbs in HCV-infected subjects [70]. In chronic HCV-infected subjects autoimmune hemolyticanemia is associated with ANA and MC positivity while subjects with HCV-infection and autoimmune thrombocytopenia had been observed to have antiplatelet antibodies.

AAbs to oxidized LDLs that have also been described and are thought to be serological marker for severity of atherosclerosis; in addition an association of these AAbs with severity of hepatitis steatosis in chronic HCV-infected subjects has been described.

\section{Systematic Autoantibody profiling in $\mathrm{HCV}$-infected subjects}

The prevalence of non-organ-specific AAbs (NOSAs; specifically ASMA, ANA and anti-liver kidney microsomal type 1 antibody (LKMA-1); Table 1) has been examined in several studies with varying results. Some authors have examined the prevalence of NOSAs versus age- and sex-matched HCV-negative subjects and found no significant difference in the NOSAs between cases and controls (18\% versus 10\%) [71].

Others however have shown higher prevalence in the HCVinfected subjects (25\%) and with chronic liver disease than in age- and sex-matched controls, including normal healthy $(6 \%)$ and HBV controls (7\%; HbsAg positive). NOSAs seen in this study were generally low titre and not directed against well definedantigens (e.g. F-actin in ASMA) [72]. This is similar to findings from Granito, et al. [73] in which none of the HCV-infected subjects tested by IIF had detectable ASMA VGT (VGT=vascular, glomerular and tubular) staining; a pattern usually associated with F-acting antibodies as opposed to ASMA V or ASMA VG staining, which are less specific for autoimmune hepatitis (AIH). Of note, many studies in HCV-infected subjects do not distinguish between these patterns despite their differing clinical predictive value for $\mathrm{AIH}$.

NOSA positive individuals however may have higher levels of alkaline phosphatase, lower levels of platelets and prothrombin activity and increased prevalence of significant fibrosis suggesting possible association between NOSA positivity and biochemical and histological profile of HCV [74]. In a US population, a retrospective review of AAbs (as above and with the addition of RF, AMA and MC) in HCV-exposed subjects with elevated serum amino transferases $(n=117)$ showed a high prevalence of positivity, particularly for ASMAs (66\%) and RF (76\%), in both men and women [75]. However, the study did not appear to include age- or sex-matched controls.

In a recent Egyptian paediatric population with chronic HCV GT4 infection $(n=80)$, tested for the same set of NOSAs, $40 \%$ exhibited evidence of low to moderate titre ASMA without associated ANA or LKMA-1 but non-typical clinical features usually associated with the presence of ASMA. Nevertheless, it was found that HCV infected subjects with ASMA had higher levels of total bilirubin, albumin, immunoglobulins, alkaline phosphatase, and gamma-glutamyl transferase levels [76]. In addition, adult data suggests there may also be an association between ASMA antibody and degree of liver fibrosis [77].

ANA positivity (titre $\geq 80$ ) appears to be an immunological epiphenomenon that does not influence clinical, biochemical or histological features of chronic hepatitis, or predict response to anti-viral treatment [78]. A large UK study of 963 chronic HCV 
positive subjects reported a significant relationship between ASMA positivity and interface hepatitis in males, and that ANA was associated with increased age consistent with the frequencies reported in blood donors. The outcome of these reports suggests that ASMA may be associated with histological features of liver damage, while the association between ANA and clinical correlates remain unclear [77-80].

\section{Conclusion}

This review reflects on the current evidence for AAbs in HCV from a Clinical Immunology aspect. Although there is clear evidence for certain types of autoimmune disease in HCVinfected subjects, less is known about additional predisposing risk factors. Based on the current evidence, routine screening for thyroid autoimmunity and $\mathrm{MC}$ is recommended, however, the role of screening for other types of autoimmunity beyond these is less clear and should be performed only if the clinical suspicion of an autoimmune disease arises. Further studies in the field are urgently needed, as the time of initiation of treatment with DAAs may be critical to prevent future life-long autoimmune disease in some subjects.

\section{References}

1. Zignego AL, Giannini C, Monti M, Gragnani L (2007) Hepatitis C virus lymphotropism: lessons from a decade of studies. Dig Liver Dis 39 Suppl 1: S38-45.

2. Jablonska J, Zabek J, Pawelczyk A, Kubisa N, Fic M, et al. (2013) Hepatitis C virus (HCV) infection of peripheral blood mononuclear cells in patients with type II cryoglobulinemia. Human immunology 74: 1559-1562.

3. Zignego AL, Giannelli F, Marrocchi ME, Mazzocca A, Ferri C, et al. $(2000) \mathrm{T}(14 ; 18)$ translocation in chronic hepatitis $\mathrm{C}$ virus infection. Hepatology 31: 474-479.

4. Zignego AL, Giannelli F, Marrocchi ME, Giannini C, Gentilini P, et al (1997) Frequency of bcl-2 rearrangement in patients with mixed cryoglobulinemia and HCV-positive liver diseases. Clin Exp Rheumatol 15 (6): 711-712.

5. Zignego AL, Ferri C, Giannelli F, Giannini C, Caini P, et al. (2002) Prevalence of bcl-2 rearrangement in patients with hepatitis $C$ virusrelated mixed cryoglobulinemia with or without B-cell lymphomas. Ann of internal medicine 2002;137:571-80.

6. Chen Z, Zhu Y, Ren Y, Tong Y, Hua X, et al. (2011) Hepatitis C virus protects human B lymphocytes from Fas-mediated apoptosis via E2CD81 engagement. PloS one 6(4): e18933.

7. Musset L, Lunel F, Cacoub P, Mannant PR, Silvain C, et al. (1995) Increased serum immunoglobulin G1 levels in hepatitis C virus infection. Hepatology 21(6): 1755-1757.

8. Charles ED, Dustin LB (2009) Hepatitis C virus-induced cryoglobulinemia. Kidney Int 76(8): 818-824.

9. Nakashima K, Takeuchi K, Chihara K, Horiguchi T, Sun X, et al. (2012) HCV NS5A protein containing potential ligands for both Src homology 2 and 3 domains enhances autophosphorylation of Src family kinase Fyn in B cells. PloS one 7(10): e46634.

10. Roughan JE, Reardon KM, Cogburn KE, Quendler H, Pockros PJ, et al. (2012) Chronic Hepatitis C Virus Infection Breaks Tolerance and
Drives Polyclonal Expansion of Autoreactive B Cells. Clin Vaccine Immunol 19(7): 1027-1037.

11. Lleo A, Invernizzi P, Gao B, Podda M, Gershwin ME (2010) Definition of human autoimmunity--autoantibodies versus autoimmune disease. Autoimmun Rev 9(5): A259-266.

12. de Vlam K, De Keyser F, Verbruggen G, Vandenbossche M, Vanneuville B, et al. (1993) Detection and identification of antinuclear autoantibodies in the serum of normal blood donors. Clin Exp Rheumatol 11(4): 393397.

13. Hayashi N, Koshiba M, Nishimura K, Sugiyama D, Nakamura T, et al. (2008) Prevalence of disease-specific antinuclear antibodies in general population: estimates from annual physical examinations of residents of a small town over a 5-year period. Mod Rheumatol 18(2): 153-160.

14. Wiik AS (2005) Anti-nuclear autoantibodies: clinical utility for diagnosis, prognosis, monitoring, and planning of treatment strategy in systemic immunoinflammatory diseases. Scand J Rheumatol 34(4): 260-268.

15. Lleo A, Battezzati PM, Selmi C, Gershwin ME, Podda M (2008) Is autoimmunity a matter of sex? Autoimmunity reviews 7(8): 626-630.

16. Wei Q, Bundell C, Wu JS, Castley A, James I, et al. (2010) Low level of systemic autoimmunity in Western Australian multiple sclerosis patients. Mult Scler 16(3): 351-354.

17. Gregorio GV, McFarlane B, Bracken P, Vergani D, Mieli-Vergani G (2002) Organ and non-organ specific autoantibody titres and IgG levels as markers of disease activity: a longitudinal study in childhood autoimmune liver disease. Autoimmunity 35(8): 515-519.

18. van Deutekom AW, Heine RJ, Simsek S (2008) The islet autoantibody titres: their clinical relevance in latent autoimmune diabetes in adults (LADA) and the classification of diabetes mellitus. Diabet Med 25(2): 117-125.

19. Bizzaro N, Pasini P, Ghirardello A, Finco B (1999) High anti-golgi autoantibody levels: an early sign of autoimmune disease? Clin Rheumatol 18(4): 346-348.

20. Satoh M, Chan EK, Sobel ES, Kimpel DL, Yamasaki Y, etal. (2007) Clinical implication of autoantibodies in patients with systemic rheumatic diseases. Expert Rev Clin Immunol 3(5): 721-738.

21. Fritzler MJ (2011) The antinuclear antibody test: last or lasting gasp? Arthritis and rheumatism 63(1): 19-22.

22. Agmon-Levin N, Damoiseaux J, Kallenberg C, Sack U, Witte T, etal. (2014) International recommendations for the assessment of autoantibodies to cellular antigens referred to as anti-nuclear antibodies. Ann Rheum Dis 73(1): 17-23.

23. Shapira Y, Agmon-Levin N, Shoenfeld Y (2010) Defining and analyzing geoepidemiology and human autoimmunity. J Autoimmun 34(3): J168-J177.

24. Cornberg M, Razavi HA, Alberti A, Bernasconi E, Buti M, et al. (2011) A systematic review of hepatitis $C$ virus epidemiology in Europe, Canada and Israel. Liver Int 31(Suppl 2): 30-60.

25. Antonelli A, Ferri C, Fallahi P, Ferrari SM, Ghinoi A, et al. (2006) Thyroid disorders in chronic hepatitis $C$ virus infection. Thyroid 16(6): 563572.

26. Mao XR, Zhang LT, Chen H, Xiao P, Zhang YC (2014) Possible factors affecting thyroid dysfunction in hepatitis $\mathrm{C}$ virus-infected untreated patients. Exp Ther Med 8(1): 133-140.

27. Fallahi P, Ferrari SM, Politti U, Giuggioli D, Ferri C, et al. (2014) Autoimmune and neoplastic thyroid diseases associated with hepatitis C chronic infection. Int J Endocrinol 2014: 935131. 
28. Lenzi M, Johnson PJ, McFarlane IG (1991) Antibodies to hepatitis $\mathrm{C}$ virus in autoimmune liver disease: evidence for geographical heterogeneity. Lancet 338: 277-280.

29. Antonelli A, Ferri C, Pampana A, Fallahi P, Nesti C, et al. (2004) Thyroid disorders in chronic hepatitis C. Am J Med 117(1):10-13.

30. Fallahi P, Ferrari SM, Giuggioli D, Manfredi A, Mancusi C, et al. (2014) Thyroid involvement in hepatitis C - associated mixed cryoglobulinemia. Hormones (Athens) 13(1): 16-23.

31. Pateron D, Hartmann DJ, Duclos-Vallee JC, Jouanolle H, Beaugrand M (1992) Latent autoimmune thyroid disease in patients with chronic HCV hepatitis. J Hepatol 16(1-2): 244-245.

32. Antonelli A, Ferri C, Ferrari SM, Colaci M, Sansonno D, et al. (2009) Endocrine manifestations of hepatitis $\mathrm{C}$ virus infection. Nat Clin Pract Endocrinol Metab 5(1): 26-34.

33. Antonelli A, Ferri C, Galeazzi M, Giannitti C, Manno D, et al. (2008) HCV infection: pathogenesis, clinical manifestations and therapy. Clin Exp Rheumatol 26: S39-S47.

34. Giordano TP, Henderson L, Landgren O, Chiao EY, Kramer JR, et al. (2007) Risk of non-Hodgkin lymphoma and lymphoproliferative precursor diseases in US veterans with hepatitis C virus. JAMA 297(18): 2010-2017.

35. Antonelli A, Ferri C, Fallahi P (1999) Thyroid cancer in patients with hepatitis C infection. JAMA 281(17): 1588.

36. Montella M, Crispo A, Pezzullo L, Izzo F, Fabbrocini G, et al. (2000) Is hepatitis $C$ virus infection associated with thyroid cancer? A casecontrol study. J Int Cancer 87(4): 611-612.

37. Antonelli A, Ferri C, Fallahi P, Nesti C, Zignego AL, et al. (2002) Thyroid cancer in HCV-related mixed cryoglobulinemia patients. Clin Exp Rheumatol 20(5): 693-696.

38. Antonelli A, Ferri C, Fallahi P, Pampana A, Ferrari SM, et al. (2007) Thyroid cancer in HCV-related chronic hepatitis patients: a casecontrol study. Thyroid 17(5): 447-451.

39. Fiore E, Rago T, Latrofa F, Provenzale MA, Piaggi P, et al. (2011) Hashimoto's thyroiditis is associated with papillary thyroid carcinoma: role of TSH and of treatment with L-thyroxine. Endocr-Relat Cancer 18(4): 429-437.

40. Antonelli A, Fallahi P, Ferrari SM, Carpi A, Berti P, et al. (2008) Dedifferentiated thyroid cancer: a therapeutic challenge. Biomed Pharmacother 62(8): 559-563.

41. Cacoub P, Poynard T, Ghillani P, Charlotte F, Olivi M, et al. (1999) Extrahepatic manifestations of chronic hepatitis C. MULTIVIRC Group. Multidepartment Virus C. Arthritis Rheum 42(10): 2204-2212.

42. Iagnocco A, Coari G, Mammarella A, Basili S, Donnarumma L, et al. (2004) Joint sonography in asymptomatic patients with HCV correlated hepatitis. Clin Exp Rheumatol 22(1): 43-48.

43. Palazzi C, D’Angelo S, Olivieri I (2008) Hepatitis C virus-related arthritis. Autoimmun Rev 8(1): 48-51.

44. Schellekens GA, de Jong BA, van den Hoogen FH, van de Putte LB, van Venrooij WJ (1998) Citrulline is an essential constituent of antigenic determinants recognized by rheumatoid arthritis-specific autoantibodies. J Clin Invest 101(1): 273-281.

45. Schellekens GA, Visser H, de Jong BA, van den Hoogen FH, Hazes JM, et al. (2000) The diagnostic properties of rheumatoid arthritis antibodies recognizing a cyclic citrullinated peptide. Arthritis Rheum 43(1): 155163

46. Palazzi C, Buskila D, D’Angelo S, D’Amico E, Olivieri I (2012) Autoantibodies in patients with chronic hepatitis $C$ virus infection: pitfalls for the diagnosis of rheumatic diseases. Autoimmun Rev 11(9): 659-663.
47. Wener MH, Hutchinson K, Morishima C, Gretch DR (2004) Absence of antibodies to cyclic citrullinated peptide in sera of patients with hepatitis $\mathrm{C}$ virus infection and cryoglobulinemia. Arthritis Rheumat 50(7): 2305-2308.

48. Ezzat WM, Raslan HM, Aly AA, Emara NA, El Menyawi MM, et al. (2011) Anti-cyclic citrullinated peptide antibodies as a discriminating marker between rheumatoid arthritis and chronic hepatitis C-related polyarthropathy. Rheumatol Int 31(1): 65-69.

49. Palazzi C, D’Agostino L, D’Angelo S, Petricca A, Olivieri I (2008) Acute myositis in a patient with systemic sclerosis after the administration of darbepoetin alpha. Rheumatol Int 28(3): 293-294.

50. Zehairy M, Soliman E, Daghaidy A (2012) Antibodies to mutated citrullinated vimentin in patients with chronic hepatitis $\mathrm{C}$ virus genotype IV infection-related arthropathy. Rheumatol Int 32(11): 3495-3501.

51. Al-Dahshan, Al-Dahshan TA (2012) Hepatitis C virus infection associated arthritis. J Egypt Soc of Parasitology 42(1): 33-40.

52. Bassyouni IH, Ezzat Y, Hamdy S, Talaat RM (2009) Clinical significance of anti-cyclic citrullinated peptide antibodies in Egyptian patients with chronic hepatitis C virus genotype IV infection. Clin Chem Lab Med 47: 842-847.

53. Su FH, Wu CS, Sung FC, Chang SN, Su CT, et al. (2014) Chronic hepatitis $\mathrm{C}$ virus infection is associated with the development of rheumatoid arthritis: a nationwide population-based study in taiwan. PloS one 9(11): e113579.

54. Fox RI (2005) Sjogren's syndrome. Lancet 366(9482): 321-331.

55. Toussirot E, Le Huede G, Mougin C, Balblanc JC, Bettinger D, et al. (2002) Presence of hepatitis $C$ virus RNA in the salivary glands of patients with Sjogren's syndrome and hepatitis C virus infection. J Rheumatol 29: 2382-2385.

56. Arrieta JJ, Rodriguez-Inigo E, Ortiz-Movilla N, Bartolomé J, Pardo M, et al. (2001) In-situ detection of hepatitis $C$ virus RNA in salivary glands. Am J Pathol 158(1): 259-264.

57. Ohoka S, Tanaka Y, Amako Y, Kohara M, Ishidate K, et al. (2003) Sialadenitis in patients with chronic hepatitis $\mathrm{C}$ is not directly related to hepatitis C virus. Hepatol Res 27(1): 23-29.

58. Haince JF, Houde M, Beaudry G, L'espérance S, Garon G, et al. (2010) Comparison of histopathology and RT-qPCR amplification of guanylyl cyclase $\mathrm{C}$ for detection of colon cancer metastases in lymph nodes. J Clin Pathol 63(6): 530-537.

59. Ramos-Casals M, Loustaud-Ratti V, De Vita S, Zeher M, Bosch JA, et al. (2005) Sjogren syndrome associated with hepatitis $C$ virus: a multicenter analysis of 137 cases. Medicine (Baltimore) 84(2): 81-89.

60. Christodoulou MI, Kapsogeorgou EK, Moutsopoulos HM (2010) Characteristics of the minor salivary gland infiltrates in Sjogren's syndrome. J Autoimmun 34(4): 400-407.

61. De Vita S, Damato R, De Marchi G, Sacco S, Ferraccioli G (2002) True primary Sjogren's syndrome in a subset of patients with hepatitis $C$ infection: a model linking chronic infection to chronic sialadenitis. Isr Med Assoc J 4(12): 1101-1105.

62. Vitali C (2011) Immunopathologic differences of Sjogren's syndrome versus sicca syndrome in HCV and HIV infection. Arthritis Res Ther 13(4): 233.

63. Carrozzo M, Scally K (2014) Oral manifestations of hepatitis C virus infection. World J Gastroenterol 20(24): 7534-7543.

64. Ramos-Casals M, Brito-Zeron P, Yague J, Akasbi M, Bautista R, et al. (2005) Hypocomplementaemia as an immunological marker of morbidity and mortality in patients with primary Sjogren's syndrome. Rheumatology (Oxford) 44(1): 89-94. 
65. Ioannidis JP, Vassiliou VA, Moutsopoulos HM (2002) Long-term risk of mortality and lymphoproliferative disease and predictive classification of primary Sjogren's syndrome. Arthritis and Rheum 46(3): 741-747.

66. Sutcliffe N, Inanc M, Speight P, Isenberg D (1998) Predictors of lymphoma development in primary Sjogren's syndrome. Sem Arthritis Rheum 28(2): 80-87.

67. Ramos-Casals M, la Civita L, de Vita S, Solans R, Luppi M, et al. (2007) Characterization of B cell lymphoma in patients with Sjogren's syndrome and hepatitis C virus infection. Arthritis Rheumat 57(1): 161-170.

68. Vergani D, Mieli-Vergani G (2013) Autoimmune manifestations in viral hepatitis. Semin Immunopathol 35: 73-85.

69. Ramos-Casals M, Stone JH, Cid MC, Bosch X (2012) The cryoglobulinaemias. Lancet 379(9813): 348-360.

70. Himoto T, Masaki T (2012) Extrahepatic manifestations and autoantibodies in patients with hepatitis C virus infection. Clin Dev Immunol 2012: 871401.

71. Muratori P, Muratori L, Stroffolini T, Pappas G, Terlizzi P, et al. (2003) Prevalence of non-organ specific autoantibodies in HCV-infected subjects in the general population. Clin Exp Immunol 131(1): 118-121.

72. Vergani D, Alvarez F, Bianchi FB, Cançado EL, Mackay IR, et al. (2004) Liver autoimmune serology: a consensus statement from the committee for autoimmune serology of the International Autoimmune Hepatitis Group. J Hepatol 41(4): 677-683.

73. Granito A, Muratori L, Muratori P, Pappas G, Guidi M, et al. (2006) Antibodies to filamentous actin (F-actin) in type 1 autoimmune hepatitis. J Clin Pathol 59(3): 280-284.

74. Marconcini ML, Fayad L, Shiozawa MBC, Dantas-Correa EB, Lucca Schiavon Ld, et al. (2013) Autoantibody profile in individuals with chronic hepatitis C. Rev Soc Bras Med Trop 46(2): 147-153.

75. Clifford BD, Donahue D, Smith L, Cable E, Luttig B, et al. (1995) High prevalence of serological markers of autoimmunity in patients with chronic hepatitis C. Hepatology 21(3): 613-619.

76. Hamed ME, Kamal Alanani NM, Sherief LM, Fouad MA, Elwahab LA et al. (2013) Study of non-organ-specific antibodies in children with genotype 4 chronic hepatitis C. Saudi J Gastroenterol 19(6): 262-270.

77. Andrade LJ, Melo PR, Atta AM, Atta ML, Jesus LS, et al. (2011) Smooth muscle antibodies and cryoglobulinemia are associated with advanced liver fibrosis in Brazilian hepatitis $C$ virus carriers. Braz J Infect Dis 15(1): 66-68.

78. Narciso-Schiavon JL, Freire FC, Suarez MM, Ferrari MV, Scanhola GQ, et al. (2009) Antinuclear antibody positivity in patients with chronic hepatitis C: clinically relevant or an epiphenomenon? Eur J Gastroenterol Hepatol 21(4): 350-356

79. Lenzi M, Bellentani S, Saccoccio G, Muratori P, Masutti F, et al. (1999) Prevalence of non-organ-specific autoantibodies and chronic liver disease in the general population: a nested case-control study of the Dionysos cohort. Gut 45(3): 435-441.

80. Williams MJ, Lawson A, Neal KR, Ryder SD, Irving WL (2009) Autoantibodies in chronic hepatitis $\mathrm{C}$ virus infection and their association with disease profile. J Viral Hepat 16(5): 325-331.

\section{Your next submission with Juniper Publishers} will reach you the below assets

- Quality Editorial service

- Swift Peer Review

- Reprints availability

- E-prints Service

- Manuscript Podcast for convenient understanding

- Global attainment for your research

- Manuscript accessibility in different formats ( Pdf, E-pub, Full Text, Audio)

- Unceasing customer service

Track the below URL for one-step submission https://juniperpublishers.com/online-submission.php 